\title{
Obraz amerykańskiego Zachodu w powieści Rącze konie Cormaca McCarthy'ego
}

Anna Dulska | Wydział Filologiczny, Uniwersytet Gdański

\section{Streszczenie}

Słowa kluczowe:

amerykański

Zachód

pogranicze

Meksyk, Rącze konie

W artykule poddano analizie obraz amerykańskiego Zachodu, jaki wyłania się z powieści Rącze konie C. McCarthy'ego. Celem analizy jest wykazanie, w jaki sposób obraz Zachodu przedstawiony w tejże powieści różni się od powszechnego wyobrażenia o regionie.

The Depiction of the American West in Cormac McCarthy's All the Pretty Horses

Abstract

Keywords: The paper examines the myth of the American West presented in C. McCarthy's novel All the Pretty Horses. The aim of the analysis is to show the differences between the common image of the region and the one presented in the novel. 


\section{Wprowadzenie}

Wydawało się, że świat stoi otworem przed trzydziestotrzyletnim Cormakiem McCarthy'm, stypendystą Amerykańskiej Akademii Sztuki i Literatury, laureatem grantu Fundacji Rockefellera (Lincoln 2009: 6), kiedy w 1966 roku odebrał nagrodę Fundacji im. Williama Faulknera za debiutancką, wydaną rok wcześniej powieść Strażnik Sadu (The Orchard Keeper). Jednakże, mimo uznania krytyków literackich, książka nie przyniosła pisarzowi spodziewanego sukcesu komercyjnego, sprzedając się w liczbie zaledwie trzech tysięcy egzemplarzy (Rebein 2009: 122). Podobnie stało się w wypadku kolejnych powieści McCarthy'ego - ani W ciemność (Outer Dark) z 1968 roku, ani Dziecię Boże (Child of God) z 1974 roku, ani też Suttree, opublikowana w 1979 roku nie zdołały zdobyć dla pisarza szerszego grona czytelników, a sprzedaż każdej z nich nie przekroczyła pięciu tysięcy sztuk (Tatum 2002: 12). Większość wczesnej twórczości McCarthy'ego wpisuje się w tradycję literatury gotyckiej (Hibbard 2007), którą pisarz przejął od amerykańskiego mistrza tego gatunku, wspomnianego już Williama Faulknera. Zdaje się, że to właśnie typowo gotycka, ponura atmosfera przejawiająca się w motywach szaleństwa umysłowego głównych bohaterów, nekrofilii, kazirodztwa czy też nieposkromionej żądzy przemocy może odpowiadać za ograniczone zainteresowanie powieściami McCarthy'ego.

W 1976 roku McCarthy przeniósł się ze stanu Tennessee do południowego Teksasu, argumentując swój wybór tym, że „nie ma takiego miejsca na świecie, gdzie ludzie nie słyszeliby o kowbojach, Indianach i micie Zachodu” (Krasińska 2009: 166). Chociaż wydana w 1985 roku powieść pt. Krwawy południk albo Wieczorna łuna na Zachodzie (Blood Meridian or the Evening Redness in the West) nie spotkała się z większą uwagą ani krytyków, ani też publiczności', zasygnalizowała ona przeniesienie miejsca akcji na południowy zachód Stanów Zjednoczonych oraz do północnego Meksyku (Tatum 2002: 18) - jak się okazało, decyzja ta miała znacząco wpłynąć na dalsze losy prozy McCarthy'ego.

Rok 1992 okazał się przełomowy dla właściwie nieznanego dotychczas pisarza. W maju tego roku ukazała się bowiem pierwsza część Trylogii Pogranicza, zatytułowana Racze konie (All the Pretty Horses), która wkrótce po wydaniu dotarła na listy najlepiej sprzedających się książek w Stanach Zjednoczonych (Tatum 2002: 68-69). Powieść odniosła sukces nie tylko wśród czytelników, ale została również wysoko oceniona przez środowisko artystyczne, zdobywając prestiżowe nagrody National Book Award oraz National Books Critics Circle Award (Tatum 2002: 18-19). I chociaż pozostałym częściom Trylogii nie udało się powtórzyć spektakularnego sukcesu Rączych koni, pozycja McCarthy'ego na amerykańskiej scenie literackiej została ugruntowana.

\footnotetext{
1 Kilkanaście lat później, Harold Bloom, ceniony krytyk literatury, uznał Krwawy południk za jedną z najwybitniejszych powieści dwudziestego wieku, porównując jej epicki rozmach do Moby Dicka (Bloom 2009: 10).
} 
Zdaniem wielu krytyków literatury, sukces Rączych koni można przypisać nie tylko częściowej rezygnacji z tematyki gotyckiej, która pojawiała się w poprzednich dziełach autora, ale przede wszystkim temu, że fabuła powieści w dużej mierze została oparta na konwencji popularnego gatunku filmowego i literackiego - westernu (Tatum 2002: 70; Messent 2005: 128; Gleeson-White 2007: 23). McCarthy nie byłby jednak sobą, gdyby stworzył klasyczny western, idąc w ślady Owena Wistera, powszechnie uważanego za twórcę tego gatunku (Cawelti 1976: 215). Zatem chociaż fabuła $R q$ czych koni nawiązuje do klasycznego westernu, a główny bohater, mimo bardzo młodego wieku, w dużej mierze przypomina legendarnego kowboja z Wirgińczyka:jeźdźca $z$ równin, to jednak kilka elementów powieści zdecydowanie odcina się od założeń i reguł gatunku (Hage 2010: 22). Ta rewizjonistyczna tendencja jest szczególnie widoczna w odejściu od postrzegania Zachodu jako dzikiej i niezbadanej krainy, oferującej niezliczone możliwości. Warto więc przyjrzeć się temu, w jaki sposób McCarthy przekształca popularny obraz Zachodu, który ukształtowany został przez wcześniejszych amerykańskich pisarzy, a następnie rozpowszechniony przez tak zwane powieści groszowe (dime novels), a następnie powieść kowbojską (Plesnar 2015).

\section{Obraz Zachodu w literaturze amerykańskiej}

W 1620 roku do brzegów Nowego Świata dobił statek Mayflower, przewożący na pokładzie purytanów, którzy sprzeciwili się instytucji kościelnej w Anglii, uznając ją za moralnie zdegenerowaną i wciąż zbyt zależną od rzymskokatolickiego Kościoła (Kopcewicz, Sienicka 1983: 7-10) . Głęboko przekonani o tym, że nowy ląd został im podarowany przez Boga, purytanie opuścili Europę, aby stworzyć Nowe Jeruzalem, które miało stać się wzorem idealnego chrześcijańskiego społeczeństwa na Ziemi (Kopcewicz, Sienicka 1983: 18-20). Sytuacja kolonizacji Ameryki w okresie po wynalezieniu druku sprzyjała rozwojowi piśmiennictwa (Slotkin 1973: 19). Dzieła literackie, jakie zachowały się z czasów ekspansji, obejmują nie tylko kazania polityczno-religijne i poematy spisane przez purytańskich duchownych, takich jak na przykład Increase Mather i Cotton Mather, ale również historie poszczególnych kolonii (np. The Generall Historie of Virginia autorstwa Johna Smitha) oraz powieści związane z życiem na pograniczu (np. Pionierzy Jamesa Fenimore'a Coopera). Wiele z tych utworów przedstawiało nowy ląd w sposób wielce wyidealizowany, dając początek mitowi Ameryki jako krainy oferującej niezliczone możliwości tym, którzy przestrzegają boskich praw i wykonują ciężką, uczciwą pracę (Kowalczyk-Twarowski, Pyzik 2004: 9-10). Wraz z zagospodarowaniem wschodnich obszarów współczesnych Stanów Zjednoczonych mit ten został przeniesiony na tereny wciąż dzikie i niezbadane, rozciągające się na zachód od rzeki Mississippi, która do dzisiaj stanowi naturalną barierę pomiędzy wschodnią i zachodnią częścią Stanów Zjednoczonych.

Według prof. Richarda Slotkina sposób postrzegania Zachodu przez większość współczesnych Amerykanów został ukształtowany przede wszystkim przez literaturę 
i kulturę popularną, które doprowadziły do zniekształcenia rzeczywistego obrazu Zachodu na rzecz mitu o tym regionie (Slotkin 1998: 61-62). Slotkin stwierdza, że pierwotnym ideologicznym założeniem mitu była chęć wyjaśnienia oraz usprawiedliwienia osiedlania się na nowym lądzie (Slotkin 1998: 10). Po zerwaniu kontaktów z ojczyzną i skazaniu się na wygnanie (Slotkin 1973: 18) pierwsi osadnicy znaleźli się w zupełnie obcym dla siebie środowisku, które wymagało od nich niezwykłej siły charakteru, determinacji i odwagi, aby przetrwać w wyjątkowo trudnych warunkach. Z drugiej strony osadnicy byli z pewnością świadomi wielkiego potencjału nowo odkrytego lądu, który krył się w rozległych połaciach ziemi, urodzajnych glebach, gęstych lasach i strzelistych górach. Przebiegająca w kierunku zachodnim kolonizacja nowych obszarów była utożsamiana z postępem, gdyż niosła ze sobą cywilizację oraz chrześcijaństwo (Slotkin 1998: 11, 446). Chociaż zarówno spuścizna kulturowa, jak i wierzenia większości pierwszych osadników wywodziły się z Europy, uważali oni, że poprzez odseparowanie się od reszty świata, powrót do prymitywnych warunków życia oraz walkę z siłami przyrody, uwieńczoną zagospodarowywaniem coraz dalszych terenów, staną się lepszymi moralnie ludźmi (Slotkin 1998: 10-11). Nie bez znaczenia dla rozwoju mitu pozostawał również szok kulturowy wynikły ze zderzenia kultury europejskiej z zupełnie odmiennymi obyczajami i tradycjami rdzennych mieszkańców Ameryki (Slotkin 1998: 12-13). Zgodnie z purytańskim światopoglądem Indianie byli narzędziem szatana, zesłanym na osadników w celu powstrzymania postępującej budowy idealnego chrześcijańskiego społeczeństwa (Slotkin 1973: 57). Taki pogląd nie tylko usprawiedliwiał zajmowanie przez osadników ziem, które były przecież przez wieki użytkowane przez Indian, ale również dawał im przyzwolenie na eksterminację rdzennej ludności pod pretekstem pełnienia woli Bożej. Z drugiej strony w twórczości niektórych amerykańskich pisarzy, takich jak Sarah F. Wakefield czy James Fenimore Cooper, zaczęła pojawiać się również postać dobrego Indianina, określanego mianem "szlachetnego dzikusa” (Plesnar 2015: 134)². Warto jednak wspomnieć, że głębokie przekonanie o tym, iż Indianie stanowią przeszkodę na drodze postępu cywilizacyjnego istniało jeszcze pod koniec dziewiętnastego wieku, o czym między innymi świadczyć może kilkutomowa saga pt. The Winning of the West, napisana przez Theodora Roosevelta (Slotkin 1998: 52-53).

W okresie kolonizacji w literaturze Nowej Anglii znaczącą pozycję zajmowała tematyka wojen z Indianami oraz tak zwane opowieści o uprowadzeniu (Slotkin 1973: 66). W różnego rodzaju tekstach często pojawiał się również motyw odrodzenia przez przemoc, zgodnie z którym akt przemocy dokonany na "barbarzyńskich" Indianach miał prowadzić do regeneracji duchowej głównego bohatera, którym najczęściej był stojący po stronie prawa i moralności nieustraszony osadnik. Co równie ważne, akt przemocy stanowił także afirmację amerykańskiego systemu wartości oraz podkreślał odrębną tożsamość narodową osadników, która w zamyśle przewyższała kulturę plemion indiańskich. Zdaje się więc, że wojny z Indianami, utrwalone w mitologii

2 Koncepcja "szlachetnego dzikusa” została szerzej rozwinięta przez myślicieli francuskiego oświecenia, w szczególności przez Rousseau, Diderota, Voltaire'a i de Chateaubrianda (Plesnar 2015: 134). 
Zachodu, odegrały istotny wpływ w wykształceniu przez Amerykanów wspólnej świadomości narodowej (Slotkin 1998: 11). Niestety, twórcy mitologii podboju nowego lądu przemilczali jego brutalny przebieg oraz tragiczny los, jaki spotkał rdzenną ludność z rąk kolonistów. Jeszcze w 1845 roku dziennikarz John O'Sullivan sformułował koncepcję Boskiego Przeznaczenia (Manifest Destiny), w myśl której Bóg powierzył Amerykanom misję zapanowania nad całym kontynentem (Plesnar 2015: 254). Niecałe pół wieku później, w 1893 roku, historyk Frederick Jackson Turner wygłosił słynny wykład pt. O znaczeniu pogranicza w amerykańskiej historii (The Significance of the Frontier in American History), w którym omówił rolę pogranicza w rozwoju amerykańskiego społeczeństwa. W przeciwieństwie do Sullivana Turner przyjął świecką postawę, pomijając aspekty religijne, a skupiając się na procesach społeczno-kulturowych i historycznych, które miały wpływ na utworzenie amerykańskiej cywilizacji. Turner natomiast, podobnie jak poprzednicy, nie podjął tematyki przemocy dokonanej na rdzennej ludności. Można zatem stwierdzić, że przeanalizował on rolę pogranicza przede wszystkim z perspektywy potomków osadników europejskich, nie zauważając wpływu innych kultur na rozwój amerykańskiego państwa. Mimo zawężonej analizy tezy o pograniczu postawione przez Turnera stanowią istotny punkt odniesienia do badań kulturoznawczych pogłębiających wiedzę na temat mitu, jaki wytworzył się wokół amerykańskiego pogranicza i Zachodu.

Według Turnera pogranicze doprowadziło do wykształcenia niezwykłych cech charakteru u kolonistów, takich jak indywidualizm, samowystarczalność, wytrzymałość, przedsiębiorczość, energiczność, odwaga i optymizm (2014: 161-162). Wykształcenie tych cech Turner przypisywał zerwaniu kontaktów z cywilizacją europejską oraz przebywaniem w prymitywnych warunkach na łonie natury, dzięki którym osadnicy odradzali się duchowo, stając się prawdziwymi amerykańskimi obywatelami (2014: 141). Ten proces, który w zasadzie odpowiadał również za wytworzenie się amerykańskiej tożsamości narodowej, Turner nazwał amerykanizacją (Americanization). Historyk ponadto uważał, że pogranicze odegrało znaczącą rolę w krzewieniu demokracji, a także sprzyjało rozwojowi wolności i równości w związku z ogromną ilością niezasiedlonej ziemi, dzięki której każdy nowo przybyły osadnik miał takie same szanse na wzbogacenie się oraz mógł na równi z innymi uczestniczyć w życiu publicznym (2014: 150-152, 157-159). Turner podsumował swój esej stwierdzeniem, że „od czasu, kiedy flota Kolumba wpłynęła na wody Nowego Świata, Ameryka jest utożsamiana z krainą możliwości" (2014: 162).

Ogłoszenie o zamknięciu zachodniej granicy, wydane przez Urząd Statystyczny Stanów Zjednoczonych pod koniec dziewiętnastego wieku (Turner 2014: 139-149), nie osłabiło wcale mitu Zachodu, a wręcz przeciwnie - w 1902 roku wydana została pierwsza powieść typu western napisana przez Owena Wistera i zatytułowana Wirgińczyk: Jeździec z równin (The Virginian: A Horseman of the Plains). W powieści tej Wister podejmuje motyw dychotomii pomiędzy dzikim, otwartym Zachodem, na którym zamieszkuje kowboj - główny bohater westernu, a zaawansowanym cywilizacyjnie 
Wschodem, z którego wywodzi się obiekt jego miłości oraz narrator. I chociaż rozwój Zachodu nie dorównuje pod względem zaawansowania Wschodowi, to jednak proste życie w zgodzie z naturą, oferowane przez Zachód, prowadzi do regeneracji duchowej i odkrycia na nowo najważniejszych wartości w życiu, brutalnie stłamszonych przez wschodnią cywilizację. Zachód u Wistera jest więc krainą niespotykanych nigdzie indziej możliwości, ale też miejscem, gdzie można schronić się przed postępem technologicznym i odzyskać siły duchowe dzięki obcowaniu z przyrodą (Cawelti 1976: 224-233). Inną istotną cechą westernu Wistera jest motyw odrodzenia przez przemoc, który pojawia się w kulminacyjnych scenach powieści. Zwycięstwo Wirgińczyka, stojącego po stronie prawa i sprawiedliwości, nad złoczyńcą i koniokradem Trampasem, reprezentującym bezprawie i barbaryzację, symbolizuje powrót cywilizacji i porządku na Zachód, a także prowadzi do regeneracji moralnej całej miejskiej społeczności.

Jak zauważa prof. Łukasz Plesnar, mity tworzone są na podstawie trzech głównych elementów - bohatera, uniwersum oraz narracji, które opisują „wzajemne interakcje bohatera i uniwersum" (2015: 31). Bohater mitu Zachodu jest zatem przedstawiony jako walcząca ze złem, wybitna jednostka, która wykazuje się nie tylko niezwykłą sprawnością fizyczną oraz inteligencją, ale posiada również prawdziwie amerykańskie cechy charakteru, wymienione przez Turnera. W zależności od daty i miejsca powstania danej narracji o micie Zachodu, jej bohater wcielał się w różne role, począwszy od pobożnego, praworządnego osadnika, niosącego ze sobą postęp cywilizacyjny oraz chrześcijaństwo (taki wizerunek bohatera dominował we wspomnianych wyżej dziełach purytańskich oraz opowieściach o uprowadzeniu), przez wyidealizowanego kowboja w postaci Wirgińczyka (Plesnar 2015: 324-325), a skończywszy na wyjętym spod prawa rewolwerowcu, który bierze sprawiedliwość w swoje ręce (taki obraz bohatera obecny jest zwłaszcza w późniejszych powieściach kowbojskich). Świat, w którym żyje tenże bohater, również poddany został mitologizacji. Chociaż na pograniczu rozmaite niebezpieczeństwa zdają się czyhać na osadników na każdym kroku, jest to jednocześnie miejsce o wyjątkowych walorach przyrodniczych oraz licznych bogactwach naturalnych, dzięki którym każdy z nowo przybyłych może nie tylko zregenerować siły witalne, ale również dorobić się majątku i awansować społecznie tak jak Wirgińczyk.

\section{Narracja: Rącze konie}

Akcja powieści rozpoczyna się w roku 1949 w południowym Teksasie. Szesnastoletni John Grady, główny bohater powieści, uczestniczy w pogrzebie swojego dziadka, ostatniego wielkiego ranczera w rodzinie, którego śmierć symbolizuje ostateczne zamknięcie ery Dzikiego Zachodu (Krasińska 2009: 172). Mimo usilnych próśb chłopca jego matka, jedyna spadkobierczyni pozostawionej przez dziadka ziemi, nie jest zainteresowana zatrzymaniem rancza, które "ledwo zarabiało na siebie przez ostatnie dwadzieścia lat" (McCarthy 1996: 17). Rodzice Johna Grady'ego są rozwiedzeni 
i nie utrzymują ze sobą kontaktu od wielu lat. Ojciec chłopca jest schorowanym weteranem drugiej wojny światowej, zupełnie nieradzącym sobie w nowej, powojennej rzeczywiści, a matka porzuciła życie na wsi dawno temu dla kariery aktorskiej w większym mieście. Nie mogąc pogodzić się z utratą ziemi i nie będąc w stanie znaleźć sobie miejsca w ucywilizowanej współczesności, John Grady, wraz z o rok starszym przyjacielem, wyrusza konno do Meksyku, aby tam urzeczywistnić marzenia o tradycyjnym życiu na ranczu. Mityczna granica zostaje przez McCarthy'ego zatem przesunięta na południe, przez co to Meksyk staje się nowym pograniczem, dającym szanse na doświadczenie prostego, kowbojskiego stylu życia, dla którego nie ma już miejsca w coraz bardziej zaawansowanej technologicznie i zurbanizowanej Ameryce (Messent 2005: 137; Gleeson-White 2007: 28; Krasińska 2009: 172). Dla dawnego pogranicza nie ma już, niestety, ratunku, gdyż zostało ono bezpowrotnie utracone na skutek nadciągającego ze wschodu postępu technologicznego i cywilizacyjnego. Już w pierwszej scenie powieści John Grady, wychodząc na prerię, jest mimowolnym świadkiem tego, w jaki sposób życie na niegdyś nieuprzemysłowionym i nieogrodzonym Zachodzie zostało zniszczone przez powojenną industrializację kraju, symbolizowaną przez ryczący pociąg, sztuczne reflektory, asfaltowe drogi, druty oraz paliki:

Ciemno, zimno, bezwietrznie i tylko cienka, szara skała zaczynająca się gdzieś na wschodnim krańcu świata. Ruszył ku prerii i przystanął, trzymając kapelusz, niczym suplikant wszechogarniającej ciemności, i stał tak przez długi czas. Kiedy chciał już odejść, usłyszał pociąg. Wstrzymał krok i czekał. Czuł go pod stopami. Nadjeżdżał z ociąganiem ze wschodu niczym sprośny giermek podnoszącego się słońca, wyjący i beczący z daleka, rzucający długą smugę światła reflektora biegnącą poprzez splątane zarośla meskitu i tworzącą z nocy nieskończenie długie ogrodzenie wzdłuż prostego jak strzała kawałka drogi, i wsysającą ją z powrotem razem z drutem i palikami mila po mili w ciemność, tam gdzie dym z tendera rozwiewał się powoli wzdłuż ledwo widocznego nowego horyzontu, i potem usłyszał opóźniony odgłos, i stał nieruchomo, trzymając kapelusz w dłoni, gdy mijała go drżąca ziemia, i patrzył, dopóki pociąg nie zniknął. Potem odwrócił się i poszedł z powrotem do domu (McCarthy 1996: 5-6).

Warto porównać ten fragment z opisem Meksyku, który - zupełnie jak niegdyś Zachód - jawi się jako kraj tajemniczy i niezbadany:

Mapę wydała jakaś kompania naftowa, zaznaczając na niej głównie drogi. Studiowali ją, a potem przenosili wzrok na południe ku wyłomowi w niskich pagórkach. Po amerykańskiej stronie mapy były drogi, rzeki i miasta, aż do Rio Grande na południu, a dalej wszystko było białe.

Niczego tam nie zaznaczyli, co nie? spytał Rawlins.

No.

Myślisz, że nie mają tam map?

Mają mapy. Tylko inne. Mam taką jedną w jukach.

Rawlins wrócił z mapą, usiadł na ziemi i przejechał ich trasę palcem. Podniósł głowę.

Co? spytał John Grady.

Nic tam [...] nie ma. (McCarthy 1996: 35-36). 


\subsection{Bohater: John Grady}

Mimo nastoletniego wieku John Grady został przedstawiony jako klasyczny bohater mitu Zachodu. Ucieleśnia on bowiem wszystkie pozytywne cechy charakteru, a także charakteryzuje się wyjątkową sprawnością fizyczną i zwinnością oraz ponadprzeciętnym intelektem. Co więcej, Grady zawsze opowiada się po stronie prawdy, dobra i sprawiedliwości, często ryzykując przy tym własne życie. Grady stoi zatem na straży prawa reprezentowanego przez cywilizację białych osadników, nie potrafi jednak odnaleźć się we współczesnym świecie, w którym nie jest w stanie zrealizować swoich marzeń o tradycyjnym życiu na Zachodzie. Tęsknota Grady'ego za dawnym pograniczem objawia się nie tylko w chęci zatrzymania rancza, ale także $w$ jego snach, w których stałym elementem są konie:

Tej nocy śniły mu się konie na wysokiej prerii, gdzie wiosenne deszcze obudziły uśpioną w ziemi trawę i dzikie kwiaty, błękitne i żółte, rosnące wszędzie, gdzie okiem sięgnąć, i w tym śnie był pośród biegnących koni i widział siebie biegnącego jak konie, i razem z nimi okrążał młode klacze i źrebaki na pastwisku, a ich mocne gniade i kasztanowe zady świeciły w słońcu, młode ogiery biegły za matkami, tratując kwiaty sypiące mgłą pyłków, unoszącą się w słońcu jak sproszkowane złoto, i cwałowały dalej, a on razem z nimi, i wszyscy pędzili mesą pośród gór, a ziemia dudniła od kopyt, i płynęli, zmieniali się i biegli, a ich grzywy i ogony rozwiewały się na wietrze jak piana, i oprócz nich nie było niczego na tym górzystym świecie, i sunęli złączeni ze sobą harmonią (McCarthy 1996: 157).

Konie w powieści symbolizują siły przyrody i wolę życia (Tatuum 2002: 46-47). Co więcej, przypominają one o tradycyjnej więzi łączącej człowieka z naturą, która w Stanach Zjednoczonych została na zawsze zerwana przez rozwój technologiczny i cywilizacyjny.

\subsection{Granica: Rio Grande}

Rzeka Rio Grande stanowi naturalną granicę oddzielającą Stany Zjednoczone od Meksyku. W Rączych koniach zyskuje ona wymiar metafizyczny, wyznaczając granicę pomiędzy cywilizacją, reprezentowaną przez Amerykę, a dziką, nieokiełznaną przez człowieka przyrodą, uosabianą przez Meksyk (Gleeson-White 2007: 28-29). Istotnym faktem wydaje się również to, że bohaterowie powieści przekraczają rzekę nago, niejako poddając się rytuałowi fizycznego i duchowego oczyszczenia przed wstąpieniem do bram Nowego Świata (Tatum 2002: 38). Być może przejście przez rzekę stanowi również nawiązanie do losu pierwszych purytanów, którzy - aby dotrzeć do upragnionego lądu - musieli przebyć długą drogę przez wody oceanu.

\subsection{Nowe uniwersum: Meksyk}

Hacienda de Nuestra Señora de la Concepción Purísima, do której po pełnej trudów podróży docierają bohaterowie, przedstawiona została jako raj na Ziemi (Sickels, Oxoby 
2002: 349; Gleeson-White 2007: 29). W odróżnieniu od charakterystycznego dla Meksyku suchego, pustynnego terenu, na tym rozległym, porośniętym gęstą i bujną roślinnością ranczu znajdują się liczne naturalne źródła, nieskazitelnie czyste strumienie, a nawet jeziora, w których „pływały ryby nieznane w innych częściach świata, a wszędzie pełno było ptaków, jaszczurek i przeróżnych zwierząt uznawanych gdzie indziej za wymarłe" (McCarthy 1996: 96). Ranczo znajduje się w posiadaniu jednej rodziny od 170 lat, a jego obecny właściciel - Don Hector Rocha y Villareal - zajmuje się wypasem bydła, a także prowadzi hodowlę koni, których jest wielkim miłośnikiem. Wydaje się więc, że dwóch młodych Amerykanów rzeczywiście odnalazło mityczny Zachód, w którym czas zatrzymał się w miejscu, umożliwiając im proste życie na łonie przyrody u boku prawdziwego kowboja, na jakiego kreowany jest Don Hector. Istotne wydaje się również to, że John Grady i jego przyjaciel otrzymują pracę stajennych, dzięki czemu mogą w pełni powrócić do życia w zgodzie z przyrodą.

Jednakże pewnego dnia John Grady, wychodząc ze stajni, niespodziewanie widzi odlatujący nieopodal samolot. Motyw maszyny, który pojawił się już na samym początku powieści $w$ formie pociągu, zdaje się sugerować, że ranczo nie jest wcale rajem, niepodlegającym regułom upływu czasu, a jedynie iluzją, podtrzymywaną przez jego właściciela. Jak wkrótce wychodzi na jaw, Don Hector regularnie odwiedza stolicę Meksyku, w której posiada drugi dom i w której na stałe mieszka jego żona (Sickels, Oxoby 2002: 350). Podobne życie wiedzie także jego córka - Alejandra, która uczęszcza do elitarnej szkoły w stolicy, a w wolnych chwilach przyjeżdża na ranczo, aby spotkać się z ojcem. I to właśnie piękna siedemnastoletnia Meksykanka doprowadzi głównego bohatera do zguby.

Romans, jaki w niedługim czasie nawiązuje się pomiędzy Alejandrą, pochodzącą z bogatej, arystokratycznej rodziny, i Johnem Grady'm, ubogim, lecz pracowitym i uczciwym kowbojem, jest z góry skazany na klęskę. Jak się bowiem okazuje, Meksyk nie jest w stanie przejąć funkcji mitycznego Zachodu, gdzie wszyscy są sobie równi, a wartość człowieka mierzona jest jego pracowitością i prawością charakteru. Zacofanie technologiczne, dzięki któremu Meksyk pozostaje w dalszym ciągu enigmatyczną, nieucywilizowaną krainą, prowadzi jednocześnie do bezprawia, którego dopuszczają się nawet osoby reprezentujące wymiar sprawiedliwości i które przyczynia się do utrzymania skostniałych podziałów klasowych (Bell 1992: 926; Hage 2010: 145146). Ci zaś, którzy spróbują je podważyć, ryzykują wykluczeniem z meksykańskiego społeczeństwa lub nawet śmiercią, o czym John Grady przekona się na własnej skórze.

Po odkryciu romansu córki Don Hector wydaje Johna Grady'ego lokalnym policjantom, którzy oskarżają młodego Amerykanina o kradzież koni, a następnie bez procesu sądowego i bez udowodnienia winy zamykają go w jednym z meksykańskich więzień. Zdaje się zatem, że meksykańska policja nie stoi po stronie prawa, jak czynili to legendarni szeryfowie na Dzikim Zachodzie, a reprezentuje interesy ludzi wpływowych i majętnych. Wartości takie jak odwaga czy prawda nie mają znaczenia dla 
skorumpowanego kapitana policji, który uważa Johna Grady'ego za szalonego, dodając, że prawda leży zawsze po stronie silniejszego:

Masz okazję mówić tu prawdę. Tutej. Za trzy dni jedziesz do Saltillo i tam nie masz już tej okazji. Tam nie będzie. Tam prawda będzie w innych rękach. Rozumiesz. Tutej razem pokazujemy prawdę. Albo prawda znika (McCarthy 1996: 163-164).

Podobne poglądy wyraża Perez, wpływowy współwięzień, usiłujący wyleczyć Johna Grady'ego z romantycznych ideałów, które według niego nie mają racji bytu w kraju takim jak Meksyk.

Znamienne jest to, że John Grady nie opuszcza więzienia w wyniku własnych działań, lecz dlatego że zostały za niego wpłacone pieniądze przez ciotkę Alejandry. Jest to jawne zakwestionowanie mitu Zachodu, zgodnie z którym każdy może sam zadecydować o swoim dalszym losie (Messent 2005: 142-143). Meksyk nie oferuje Grady'emu niezliczonych możliwości ani też nie prowadzi do jakiejkolwiek regeneracji duchowej. Wręcz przeciwnie, Meksyk staje się miejscem, w którym John Grady doświadcza zawodu miłosnego, gdy naiwnie próbuje przełamać anachroniczne bariery kulturowe, społeczne i ekonomiczne (Messent 2005: 134). Związek kowboja z dawnego Zachodu i kobiety reprezentującej cywilizację nie ma bowiem w Rączych koniach tak szczęśliwego zakończenia jak w Wirgińczyku. Mimo iż Alejandra uwielbia spędzać czas na ranczu ojca, nie wiąże z nim przyszłości. W przeciwieństwie do Johna Grady'ego, który nie może odnaleźć się we współczesnym cywilizowanym świecie, marząc o tradycyjnym życiu kowboja, Alejandra mieszka w samej stolicy kraju, a przyjazd na ranczo traktuje bardziej jako rozrywkę niż źródło utrzymania (Sickels, Oxoby 2002: 350). Wydaje się też, że mimo buntowniczej natury nie jest ona $w$ stanie sprzeciwić się woli rodziny i zrezygnować $z$ luksusów w imię miłości. Kiedy więc zostaje postawiona przed wyborem pomiędzy dotychczasowym, dostatnim życiem a zubożałym kochankiem, nieuchronnie wybiera to pierwsze.

Meksyk jest także miejscem, w którym John Grady po raz pierwszy stanie oko w oko ze złem i zabije drugiego człowieka (Tatum 2002: 54). Pojedynek na noże w więzieniu stanowi punkt zwrotny Rączych koni, gdyż przeistacza głównego bohatera z biernej ofiary przemocy w niezłomnego orędownika prawdy i dobra, który ostatecznie bierze sprawiedliwość we własne ręce, mszcząc się na kapitanie policji (Brewton 2009: 76-77). W przeciwieństwie do mitu Zachodu, zgodnie z którym akt przemocy miał przynosić odnowę duchową, John Grady doświadcza jednak jedynie zła i cierpienia, a więc ani zwycięstwo $w$ więziennym pojedynku, ani też zemsta dokonana na meksykańskim kapitanie nie prowadzą do moralnego odrodzenia. „Świat jest bezwzględnym miejscem i szybko odsiewa marzenia od rzeczywistości, nawet wbrew naszej woli. Czyha na nas pomiędzy życzeniem a spełnieniem" (McCarthy 1996: 229) - mówi Duena Alfonsa, która na własne oczy widziała ogrom okrucieństwa, jakie niosła ze sobą rewolucja meksykańska. Idea regeneracji przez przemoc zostaje zatem 
zastąpiona przez McCarthy'ego koncepcją wszechobecnego zła, przed którym próżno szukać schronienia.

Chociaż w kulminacyjnej scenie strzelaniny powieść zdaje się powracać do konwencji westernu, to jednak okazuje się, że we współczesnym świecie nie ma już możliwości doświadczenia życia na mitycznym Zachodzie ani skorzystania z jego dobrodziejstw, gdyż kraina ta po prostu nie istnieje (Kollin 2001: 575-576).

Przy ostatecznym pożegnaniu kochanków po raz kolejny pojawia się motyw maszyny - ponownie w postaci pociągu, który wskazuje na nieodwracalność i nieuniknioność zmian w społeczeństwie. Nic nie trwa wiecznie - zdaje się mówić McCarthy i nie istnieje żadne miejsce, w którym można by się schronić przed nadchodzącą zmianą (Bourne 2009: 124). Tych, którzy żyją marzeniami o wspaniałej przeszłości, czeka zaś tułaczka we współczesnej rzeczywistości, tak jak Johna Grady’ego, który na końcu powieści odjeżdża konno w nieznanym kierunku na tle zachodzącego słońca.

\section{Konkluzje}

Chociaż dynamiczny rozwój technologiczny, przemysłowy i gospodarczy Stanów Zjednoczonych w XX wieku doprowadził do zniszczenia tradycyjnego stylu życia na dawnym pograniczu, nie obalił silnie zakorzenionego mitu o tej krainie. W obliczu gwałtownego uprzemysłowienia Teksasu, niegdysiejszej kolebki Dzikiego Zachodu, John Grady wyrusza do Meksyku, aby tam szukać spełnienia marzeń o życiu kowboja. W Rączych koniach okazuje się jednak, że mit Zachodu jako krainy dzikiej i bezkresnej może funkcjonować jedynie na amerykańskiej ziemi. Chociaż Meksyk nie uległ jeszcze poważniejszym przemianom technologicznym i industrializacyjnym, nie jest w stanie przejąć symbolicznej roli, jaką Zachód pełni w amerykańskiej świadomości narodowej.

Zważywszy na stosunkowo negatywny obraz Meksyku, jaki wyłania się z Rączych koni, należałoby się jeszcze zastanowić, czy powieść ta nie stanowi próby promowania przez autora ideologii kolonizatorów, którą doskonale oddaje wspomniana wyżej doktryna Objawionego Przeznaczenia. Rzeczywiście przemoc i zło uosabiane przez kapitana policji Pereza czy też przez więziennego nożownika stanowią jaskrawy kontrast dla kodeksu postępowania głównego bohatera powieści i jego przyjaciela oraz dla sprawiedliwego wyroku amerykańskiego sędziego w końcowym rozdziale powieści. Warto jednak zauważyć, że John Grady kilkukrotnie doświadcza również dobra ze strony mniej uprzywilejowanych mieszkańców kraju, co zdecydowanie komplikuje podział na szlachetnych Amerykanów i złowrogich Meksykanów. W innych powieściach McCarthy'ego osadzonych na pograniczu także pojawiają się liczne "czarne charaktery" ze Stanów Zjednoczonych, z których być może najbardziej na uwagę zasługuje upadły moralnie sędzia Holden z Krwawego południka. 
Czytając Rącze konie, nabiera się przeświadczenia, że postęp technologiczny jest nową formą kolonizacji, która prowadzi do zagłady cywilizacji stworzonej przez amerykańskich osadników, przypominając jednocześnie o tym, że ona sama powstała przez unicestwienie cywilizacji Indian. „Ludzie już nie czują się bezpieczni. Jesteśmy jak Komańcze przed dwustu laty. Nie wiemy, co przyniesie nam następny świt. Nie wiemy nawet, jaki będą mieli kolor" - mówi ojciec Johna Grady'ego (McCarthy 1996: 27). W smutnym zakończeniu powieści daje się odczuć wyraźną nostalgię za minionymi - zdawałoby się - lepszymi czasami, ale jednocześnie odnosi się wrażenie, że zmiany są czymś nieuchronnym w życiu człowieka, a historia - jak pokazuje los amerykańskich kolonizatorów - lubi się powtarzać.

\section{Literatura}

Bell V., 1992, "Between the wish and the thing the world lies waiting”, "Southern Review", Vol. 28, No. 4, http://web.b.ebscohost.com/Irc/detail/detail?vid=5\&sid=e2e7d54a-f172-4227-993f-a96801e62 28f\%40sessionmgr106\&hid=107\&bdata=JnNpdGU9bHJjLWxpdmU\%3d\#AN=9610111079\&db=Ifh [dostęp: 1.09.2016].

Bloom H., 2009, Cormac McCarthy, Philadelphia: Chelsea House Publishers.

Bourne A., 2009, „Plenty of Signs and Wonders to Make a Landscape”: Space, Place, and Identity in Cormac McCarthy's Border Trilogy, "Western American Literature”, Vol. 44, No. 2.

Brewton V., 2009, The Changing Landscape of Violence in Cormac McCarthy's Early Novels and the Border Trilogy [w:] Cormac McCarthy, ed. H. Bloom, Philadelphia: Chelsea House Publishers.

Cawelti J.G., 1976, Adventure, Mystery, and Romance: Formula Stories as Art and Popular Culture. Chicago: The University of Chicago Press.

Gleeson-White, S., 2007, Playing Cowboys: Genre, Myth and Cormac McCarthy's "All the Pretty Horses", "Southwestern American Literature" Vol. 33, No. 1, http://web.a.ebscohost.com//rc/pdfviewer/ pdfviewer?vid=2\&sid=d30e1dcb-3882-4a4e-af97-f780150747c5\%40sessionmgr4010\&hid=4207 [dostęp: 1.09.2016].

Hage E., 2010, Cormac McCarthy: A Literary Companion, Jefferson: McFarland \& Company.

Hibbard A., 2007, Cormac McCarthy [w:] Magill's Survey of American Literature, http://search.ebscohost.com/login.aspx?direct=true\&db=Ifh\&AN=MOL9830000192\&site=Irc-live [dostęp: 1.09.2016].

Kollin S., 2001, Genre and the Geographies of Violence: Cormac McCarthy and the Contemporary Western, „Contemporary Literature” Vol. 42, No. 3, http://search.ebscohost.com/login.aspx?direct=true $\& d b=$ Ifh \&AN=5488332\&site=Irc-live [dostęp: 1.09.2016].

Kopcewicz A., Sienicka M., 1983, Historia literatury amerykańskiej w zarysie: wiek XVII-XIX, Warszawa: Państwowe Wydawnictwo Naukowe.

Kowalczyk-Twarowski K., Pyzik T., 2004, Przedmowa [w:] Wielkie tematy literatury amerykańskiej, t. 2: "Granica", Pogranicze, Zachód, red. T. Pyzik, K. Kowalczyk-Twarowski, Katowice: Wydawnictwo Uniwersytetu Śląskiego.

Krasińska S., 2009, Tego kraju nikt nie zna: Cormac McCarthy i jego Trylogia Pogranicza [w:] Studia postkolonialne w literaturoznawstwie i kulturoznawstwie anglojęzycznym, red. M. Buchholtz, Toruń: Wydawnictwo Adam Marszałek.

Lincoln K., 2009, Cormac McCarthy: American Canticles, New York: Palgrave Macmillan. 
McCarthy C., 1993, All the Pretty Horses, London: Picador.

McCarthy C., 1996, Rącze konie, tłum. J. Polak, Poznań: Zysk i S-ka.

Messent P., 2005, "No Way Back Forever": American Western Myth in Cormac McCarthy's Border Trilogy [w:] American Mythologies: Essays on Contemporary Culture, ed. W. Blazek, M.K. Glenday, Liverpool: Liverpool University Press.

Plesnar Ł., 2015, Ziemia niczyja, ziemia obiecana. Obraz granicy w literaturze amerykańskiej, Kraków: Wydawnictwo Uniwersytetu Jagiellońskiego.

Reiben R., 2009, New West, or, The Borderlands [w:] idem, Hicks, Tribes, and Dirty Realists: American Fiction After Postmodernism. Lexington, Kentucky: The University Press of Kentucky.

Sickels R.C., Oxoby M., 2002, In Search of A Further Frontier: Cormac McCarthy's Border Trilogy, "Critique Studies in Contemporary Fiction" Vol. 43, No. 4, http://search.ebscohost.com/login.aspx?dire

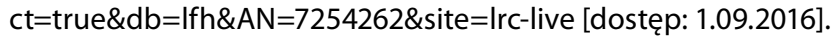

Slotkin R., 1973, Regeneration Through Violence: The Mythology of the American Frontier, 1600-1860, Norman: University of Oklahoma Press.

Slotkin R., 1998, The Gunfighter Nation: The Myth of the Frontier in Twentieth-Century America, Norman: University of Oklahoma Press.

Tatum S., 2002. Cormac McCarthy's "All the Pretty Horses": A Reader's Guide, New York-London: The Continuum International Publishing Group.

Turner F.J., 2014, O znaczeniu pogranicza w amerykańskiej historii, tłum. B. Czepil, „Pogranicze. Polish Borderlands Studies", t. 2, nr 2. 